\title{
“NA FLORESTA DO ALHEAMENTO" OU A DISSIMULAÇÃO DISCURSIVA DO SUJEITO LÍRICO SOBRE O FAZER POÉTICO
}

\author{
Maria Aparecida Rodrigues ${ }^{1}$
}

Recebido: $17 / 09 / 2015$

Aprovado: 19/06/2016

Resumo: Neste artigo, pretendo demonstrar que em "Na floresta do alheamento" (1913), texto pertencente ao conjunto de produções homônimas d'O Livro do desassossego, Fernando Pessoa concretiza a ambição de uma prosa poética cuja dimensão artística se realiza por um lirismo dialético de movimento centrípeto. Uma espécie de dissimulação discursiva do sujeito lírico sobre o fazer poético.

Palavras-chaves: Prosa poética. Literatura portuguesa. Lírica contemporânea. Dissimulação. Livro do desassossego.

\section{"IN THE FOREST OF ALIENATION" OR THE CONCEALMENT OF THE LYRIC SUBJECT ON THE DISCURSIVE DO POETIC}

\begin{abstract}
The aim of this article is to show that in "Na floresta do alheamento" (1913), a text belonging to the set of homonymic productions of the Livro do desassossego, Fernando Pessoa consolidates the ambition of a poetic prose in which an artistic dimension is acquired through a dialectic lyricism of centripetal movement. A type of discursive dissimulation of the lyrical subject about the poetic act.
\end{abstract}

Keywords: Poetic prose, Portuguese literature, Contemporary lyric. Dissimulation. Livro do desassossego.

O fragmento "Na floresta do alheamento", do Livro do desassossego, de Fernando Pessoa (1999), é a concretização de uma prosa poética cuja dimensão artística se realiza pela estrutura de palavras em razão dela própria. Lirismo dialético de movimento centrípeto no qual prevalece a dissimulação discursiva do sujeito lírico sobre o fazer poético. Enquanto forma lírica em prosa, não apresenta as contingências da versificação, embora faça uso de muitos dos caracteres fônico-semânticos do poema em verso, sem, no entanto, abandonar as múltiplas possibilidades de criação sintática. Como metalinguagem, isto é, expressão literal de si mesmo, a prosa torna-se metáfora da poesia e fecha em torno da construção do ideário da arte pela arte (autorreferente), manifesta pela voz do eu lírico.

\footnotetext{
1 Pós-Doutora pela PUC-Rio. Doutora em Teoria da Literatura pela UNESP. Mestre em Literatura Brasileira. Professora da Graduação, da Pós-Graduação e do Programa de Mestrado em Letras: Literatura e Crítica Literária, e Vice-Coordenadora do Programa em Letras, pela Pontifícia Universidade Católica de Goiás.
} 
Nesse contexto, a linguagem poética em "Na floresta do alheamento" se mostra, aos olhos do leitor, por imagens singulares, moduladas pelo ato da desautomatização. Uma arte descontínua de "textura" independente. Um jogo de palavras que ecoa outras palavras, capazes de provocar, no receptor, o encantamento, a sensação do vago, do difuso, do eterno contraste, do vazio, do múltiplo. $\mathrm{Na}$ prosa poética, os valores de signos dos símbolos subordinam-se à sua importância como estrutura de motivos interligados. Uma estrutura autônoma onde o senso de movimento pode ser captado pelo ato de "dizer", evocado pelo sujeito lírico, e pela simultaneidade, naquilo que Northrop Fry denomina de mythos e dianoia:

Ouvimos o poema quando este se move do princípio ao fim, mas, tão logo o seu conjunto esteja em nossa mente, de pronto 'vemos' o que significa. Essa reação não é simplesmente ao conjunto dele, mas a um conjunto nele: temos uma visão de sentido ou dianóia sempre que qualquer apreensão simultânea seja possível. (FRY, 2011, p. 54)

Nesse sentido, a análise tem a função básica de tentar mostrar o texto como obra de arte, como poesia pura. E, como tal, apresenta fluxo de sons que, por um lado, se aproxima do poema em verso, associado à música e à configuração integrada de imagens e, por outro, se aproxima do pictórico. Vista, desse modo, a análise pode ser transformada em produto do "saber em si", isto é, por meio dos fonemas, das palavras, das frases ou imagens da composição em estudo, o leitor faz a sua apreciação crítica. Assim, o mover perceptivo do crítico-leitor segue as imagens poéticas e as examina com o objetivo de explicar sua feição distintiva. Procura traduzir em linguagem discursiva o que está implícito no texto. Isso explica a minha escolha teórica do estudo de Northrop Fry (2011) sobre a “teoria dos símbolos", em seu livro Anatomia da crítica, para a apresentação crítica que aqui passo a analisar.

Fry afirma que cada poema tem sua faixa espectroscópica específica de imagens, provocada pelas exigências de seu gênero, as predileções de seu autor e inúmeros outros fatores. Porém, o bom crítico não lê ideias dentro do poema, lê e traduz o que está lá e a prova de que está lá é oferecida pelo estudo das estruturas das imagens, com o qual começa. (FRY, 2011, p. 28). Logo, a leitura que se realiza, nesta análise, é o resultado do jogo construtivo do "ritmo (dis)sonante" e do "sentido" da floresta do alheamento de Fernando Pessoa. 


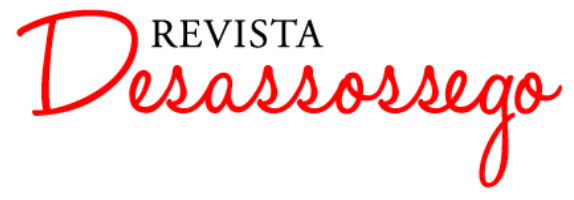

DESASSOSSEGO 15 | JUN/2016 | ISSN 2175-3180

DOI: http://dx.doi.org/10.11606/issn.2175-3180.v8i15p178-195

\section{O Dizer o Não Dito: A Habitação Polissêmica}

O texto se apresenta como parte de um todo que se estrutura, em essência, por fragmentos completos, justapostos, de existência independente, dinâmicos, móveis. Ou seja, apesar de o texto revelar-se como um dos elementos da composição do Livro do desassossego (1999), é ele, por si só, um todo completo. Assemelha-se, em parte, a um continente no espaço do globo terrestre. Distingue-se porque o seu estar não é fixo. A montagem do Livro não pré-determina sua posição nesta ou naquela parte. Enquanto forma composicional independente, o texto pertence, como já foi dito, ao gênero poético lírico em prosa e se estrutura pelo jogo discursivo entre o sujeito lírico e os signos metasimbólicos sugestivos, que se movem dialeticamente, no papel em branco. A princípio, tem-se o primeiro grande fragmento metafórico, o título: "Na floresta do alheamento". Por ele, o leitor já percebe que a análise do texto só terá sentido se passar muito mais pelo estudo de sua técnica de expressão, do que por seus conteúdos e temas. O título prenuncia o estilo anormal, a polissemia discursiva, o jogo, a metamorfose significante, o contraste, o desvio semântico. O leitor, desde o título, sente-se atraído, imerso num mistério insolúvel, num estado onírico, num encantamento desencantado, no dizer do não dito, na eterna discordância entre signo e significado: a lei que rege a lírica do texto em análise. Fernando Pessoa, nesse sentido, realiza o poetar que Mallarmé proclamou aos poetas modernos: “o renovar tão radicalmente o originário ato criativo de linguagem que o dizer seja sempre dizer o que não foi dito até então" (MALLARMÉ, 2003, p.29). Em “Na floresta do alheamento", a palavra poética não é mais o porto seguro da linguagem compreensível, mas uma dissonância insolúvel a qualquer normalidade.

O recurso estilístico de Fernando Pessoa no texto consiste no contraste fônicosemântico, na desintegração da frase em fragmento, na descontinuidade em lugar da ligação, justaposição em lugar da conjunção de elementos. O leitor, então, precisará moverse do meramente aparente às dimensões internas do texto, pois é acompanhando o mover centrípeto do ato criativo, que ele poderá apreender os sentidos que o título evoca. No mover-se o provável revelado flui do vago, semelhante a sombras movediças que se integram e desintegram continuamente, transformando-se, ao longo do texto, em "floresta estranha", em "alcova mórbida e morna", na "floresta onde de longe me vejo e sinto", na "paisagem daquele outro mundo" etc. Todo esse processo polissêmico é produzido pela relação entre duas habitações que se contrastam e se interpenetram: a linguagem padrão e a linguagem poética. Essa relação empurra o leitor para as eternas discussões dos conceitos 
fundamentais da linguagem padrão e da poética. Mukarovsky (1993), por exemplo, ao falar da linguagem poética afirma que ela não é uma variante da linguagem padrão, embora exista uma estreita relação entre as duas formas de linguagem. A poética tem a padrão como fundo e se faz pela violação da norma, pela atualização da manifestação linguística e pela avaliação estética.

Nesse sentido, quanto mais fixa é a norma de um idioma tanto mais variadas são as maneiras de transgredi-la e, por conseguinte, mais possibilidades há para a poesia e viceversa. Do mesmo modo, enquanto a linguagem-padrão adquire um caráter científico, esquemático, a linguagem poética se desautomatiza, isto é, produz a intensidade máxima de atualização. Por isso, a linguagem poética não visa à comunicação, mas ao próprio ato de expressão. Pode-se dizer, então, que a morada do crítico em literatura é a da literatura, a da erudição, a da arte enquanto arte, a do fazer poético. Compreendo, nesse contexto, o objeto deste estudo como linguagem poética, de natureza abstrata, polissêmica, dialética e onírica. A partir desse pressuposto, o título é o lugar do não-dito, a revelação do indeterminável, um marcador linguístico plurissignificativo do provável que, em essência, não se mostra de pronto. Sugere, entretanto, em imagens sinestésicas, impressões fragmentárias que se compõem múltiplos fragmentos significantes.

Para facilitar o estudo, dividi o texto em três instâncias. O termo instância relaciona-se aqui a cada uma das diferentes partes do texto poético, este considerado como elemento dinâmico, meta poético, plurissignificativo. A divisão obedece a uma das possibilidades que visualizo a partir do conceito de mythos e dianoia no ato da leitura: $1^{\text {a }}$ instância: Entre a realidade e a imagem: o jogo do contraste; $2^{\mathrm{a}}$ instância: Fusão, consciência e isolamento e $3^{\mathrm{a}}$ instância: A arte pele arte: o retorno.

\section{Entre a realidade e a imagem: o jogo do contraste}

O processo discursivo desta prosa poética, "Na floresta do alheamento", constróise com marcas contrastantes de sentido. O contraste é o traço essencial desta primeira instância. Ele acontece em vários níveis do sistema linguístico da expressão poética: no fônico, no morfo-semântico e no sintático:

Sei que despertei e que ainda durmo. O meu corpo antigo, moído de eu viver, diz-me que é muito cedo ainda... Sinto-me febril de longe. Pesome, não sei porquê...

Num torpor lúcido pesadamente incorpóreo, estagno entre o sono e a vigília, num sonho que é uma sombra de sonhar. Minha atenção bóia entre dois mundos e vê cegamente a profundeza de um mar e a 
profundeza de um céu; e estas profundezas interpenetram-se, misturamse, e eu não sei onde estou nem o que sonho. Um vento de sombras sopra cinzas de propósitos mortos sobre o que eu sou de desperto. Cai de um firmamento desconhecido um orvalho morno de tédio. Uma grande angústia inerte manuseia-me a alma por dentro e, incerta, alterame, como a brisa aos perfis das capas. (PESSOA, 1999, p. 452-3)

A princípio, no primeiro parágrafo, verifica-se o jogo sonoro entre as consoantes oclusivas /p/, /t/, /d/, /k/ e /g/ e as constritivas /s/, /r/, /f/, /v/, /m/ e /1/, e entre as surdas /s/, /k/, /t/, /f/ e /p/, e as sonoras /d/, /g/ e /v/. O jogo se completa entre as vogais abertas e semiabertas /i/ e /e/ e as fechadas e semifechadas /u/, /c/ de sei, despertei, ainda e durmo, do primeiro período. O contraste das vogais abertas e fechadas prevalece em todos os períodos do parágrafo. No primeiro, predomina a vogal aberta; no segundo e terceiro, há uma alternância entre abertas e fechadas e, no último, prevalece a fechada. A sequência de fonemas oclusivos e constritivos, surdos e sonoros, abertos e fechados promove no leitor uma sensação de vento que sopra, remetendo a um estado do entre: de sonolência. Este estado é enfatizado pelas palavras despertei e ainda durmo. Interessante é que as oclusivas surdas /p/ e / t / e, às vezes, a sonora / d/ aparecem como desvio rítmico, uma espécie de ruptura da harmonia do soprando, como se fossem pancadas repetitivas para o despertar.

Essa relação antitética e de alternância permanece no parágrafo segundo. Porém, se a alternância maior se fazia entre as consoantes $/ \mathrm{s} /, / \mathrm{d} /, / \mathrm{p} /$, e $/ \mathrm{t} /$, agora se alternam como constritivas nasais. A consoante alveolar surda /s/ e a sonora /z/ ampliam o contraste entre as vogais surdas e sonoras, reforçando mais uma vez o estado do "entre", de sonolência: entre o sono e a vigília. O jogo sonoro forma a essência do terceiro parágrafo. Em Um vento de sombras sopra cinzas de propósitos mortos sobre o que eu sou de desperto, nota-se de início a sonorização promovida pela aliteração, pela coliteração e nasalização das vogais em/un/, /en/, /on/ e /in/. Esse processo induz o leitor a perceber uma certa identificação dos fonemas com os sons do vento. O simbolismo sinestésico sugere a interiorização, uma espécie de redemoinho interior. O jogo das oclusivas e constritivas passa a predominar nos dois últimos períodos, prenunciando o despertar, isto é, a passagem de um estado a outro, a travessia inicial' ${ }^{2}$ Também, nesta primeira instância, o antagonismo e o jogo mantêm-se no nível morfo-semântico. Em "Sei

\footnotetext{
2 Denomino por travessia o movimento contínuo de essencialização artística, de realização expressiva, de constructo: movimento centrípeto.
} 


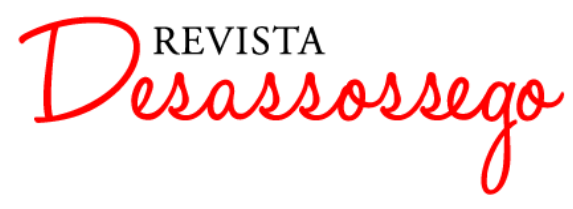

DESASSOSSEGO 15 | JUN/2016 | ISSN 2175-3180

DOI: http://dx.doi.org/10.11606/issn.2175-3180.v8i15p178-195

que despertei e que ainda durmo", verifica-se a função emotiva, marcada pela consciência do eu lírico que se expressa pelo verbo saber. O sujeito reconhece o estado de ambiguidade em que se encontra, isto é, o estar desperto e, ao mesmo tempo, o saber que ainda durmo. A antítese não é somente semântica, mas temporal, pois despertei e durmo pertencem a tempos verbais antagônicos: Sei que despertei e que ainda durmo. Do ponto de vista paradigmático, o uso do pronome relativo sugere equivalência entre as orações: Eu sei/ Eu (que) despertei/Eu (ainda) durmo.

Embora a primeira oração comande a ação, o dinamismo se faz pelo contraste: despertei / durmo; porém a presença do vocábulo ainda anula o contraste, provocando uma ambiguidade semântica: o ainda durmo evoca o não despertar. Vale lembrar que tal recurso de linguagem é uma técnica do movimento construtivo do produto artístico de Fernando Pessoa no texto, por isso ela é forma, é ato de expressão. Em "o meu corpo antigo, moído de eu viver, diz-me que é muito cedo ainda...”, há outro traço semântico importante: a consciência do sujeito é dada pelo corpo que adquire linguagem e experiência, expressos pelo verbo dizer e pelo vocábulo polissêmico antigo. O corpo passa a ser revelador da consciência enquanto sujeito do dizer e o pronome pessoal eu torna-se objeto do processo. Portanto, a consciência é do corpo. O vocábulo antigo atribuído ao corpo sugere o gasto, o experimentado, o vivido, o experiente, que contrasta com a causa: moído de eu viver e/ou a experiência adquirida pelo ato (massacrado, moído, experimentado) e da ação da experiência (viver). O ato de viver evoca a noção da vida com a experiência da fragmentação, da "corrosão" e da decadência. O viver, no entanto, só se torna consciência no resultado, isto é, o processo é o vir a ser. Fica retido na mente do leitor a noção de que Ser é Tempo enquanto experiência e é, ao mesmo tempo, a linguagem: o dizer. Daí corpo moído e corpo antigo dizem pela experiência do viver do eu lírico. Nesse contexto, o saber vem da experiência da dor, do fragmento, do massacre, do tempo vivido pelo sofrimento que ensina a ter paciência: "é muito cedo ainda...", ou seja, tempo e linguagem são resultados da experiência do viver. E é desse ato dialético (do fazer) que o poeta constrói a sua arte.

No enunciado, "Sinto-me febril de longe", a percepção, o tempo enquanto duração e a polissemia linguística formam o sentido metafórico da construção poética e da participação do sujeito agente, assinalados pelo verbo sentir e pelo termo de longe. A percepção sobrepõe a razão, daí a polissemia discursiva que sugere ao leitor a relação entre doente, fervilhar, impaciente e febril. E em "de longe", a metamorfose semântica de lugar 
passa a tempo-duração, isto é, sem expectativa, pronto para explodir, impaciente, sem ânimo, angustiado, no estado clímax de uma doença crônica. A conjunção dos termos "febril de longe" remete a um estado de permanente dor: a angústia própria da ação, do fazer, do construir artístico. Em: "peso-me, não sei porquê...”, o contraste semântico se dá pelo verbo pesar e pela causa do não saber: ...não sei porquê.... O primeiro é um desvio ao conjunto. A condensação e o volume passam à impotência: impotência do eu lírico diante de si mesmo. E o "não sei porquê..." remete ao aparente desconhecimento da causa, reforçado pela ambiguidade do questionamento indireto que também evoca um certo grau de conhecimento pela presença das reticências. Portanto, um saber não sabendo.

O senso de movimento e de simultaneidade prevalece nos períodos seguintes. Em "num torpor lúcido, pesadamente incorpóreo, estagno, entre o sono a vigília, num sonho que é uma sombra de sonhar", além do já referido jogo sonoro há uma enorme força das palavras que justapostas e antitéticas formam contrastes semânticos significativos, tais como: torpor lúcido; pesadamente incorpóreo; entre o sono a vigília e sonho que é uma sombra de sonhar.

Em o "torpor lúcido", o contraste se faz pelo estado difuso, sugerido pelo primeiro vocábulo, e a consciência do próprio estado do segundo termo. Já em "pesadamente incorpóreo", o contraste se refere ao sentido dado ao corpo do parágrafo anterior: corpo como agente. Aqui o pesar, que é adverbializado, dirige-se ao estado emocional do eu lírico e não ao do corpo, como ato físico e/ou à própria arte sendo feita. Nota-se uma oposição entre o estado do corpo e o estado do ser do sujeito lírico. O principal verbo do enunciado: estagno confirma a posição de indecisão do eu lírico e representa o estar no meio, no ponto de transição, no entre: o sono (o difuso) e a vigília (a alerta). O sentido da arte como dissimulação, como simulacro é reforçado em "estagno [...] num sonho que é uma sombra de sonhar". E pode ser assim representado:

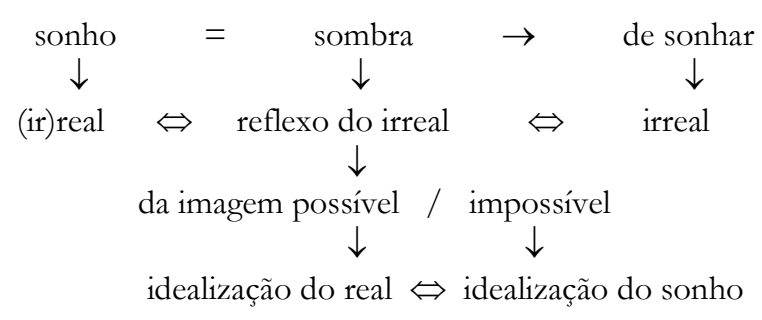

Nesse contexto, o eu lírico estaria num estado de transição permanente, entre o (ir)real que é a imagem do possível, enquanto idealização do real e a imagem do 


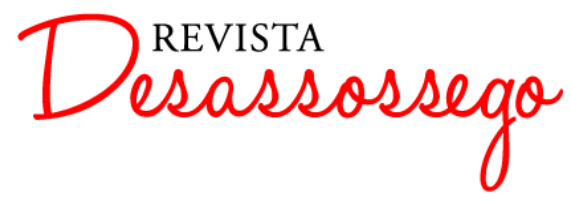

improvável, porque pertence ao sonho que, em consequência, interliga-se ao real dissimulado. Assim tem-se:
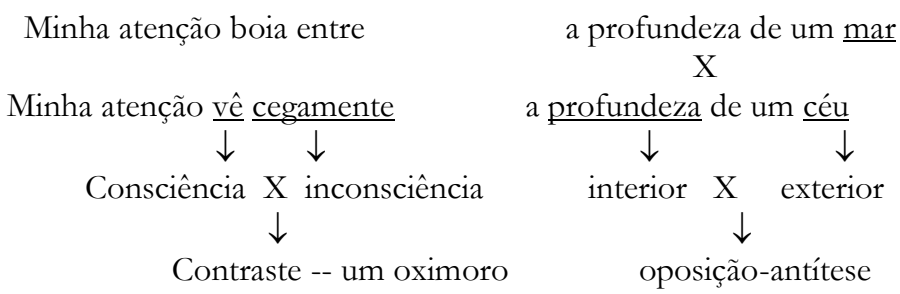

Tanto em "mar", quanto em "céu", há o simbolismo da imensidão e do movimento. Os termos se contrapõem porque "mar" evoca ao que reflete, ao que guarda segredos, à vida, à mãe, fertilidade, ambiguidade e à interiorização. Céu, em contraposição, é aquele que reveste, que se mostra e se esconde, o pai, o exterior, o que pode refletir-se no mar. Dessa forma, o sentido do céu e do mar se interpenetram e se misturam. O jogo desses vocábulos remete o receptor ao conceito da arte simbolista. Desse modo, há no texto poético em análise uma integração dos contrários, uma íntima relação das essências antagônicas que se tornam caos, e se transformam em massa desconexa, difusa:

Eu não sei onde estou $\rightarrow$ realidade (estar) $=$ desconhecimento do espaço, provocado pelo caos anterior

Eu nem sei o que sonho $\rightarrow$ o irreal (percepção onírica) $=$ desconhecimento do sonho da própria (ir)realidade.

Logo, no "torpor lúcido", a imagem da imagem penetra no difuso que, em outras palavras, são as profundezas antagônicas dos seres e das coisas, inerentes ao ato do viver e do criar artístico, gerando, daí, o caos próprio da (in)consciência onírica e, ao mesmo tempo, físico- espacial do sujeito lírico. Os sentidos do entre e do contraste pertencem à consciência do sujeito lírico, marcados, linguisticamente, pelo pronome possessivo, pelos substantivos e pelo verbo de "Minha atenção boia entre dois mundos...". Dessa maneira, o ato de flutuar (de dentro para fora, do interior para o exterior e do referencial para o difuso e desconhecido) evoca o entre, o portal. Pode-se afirmar, assim, que o poeta é, também, uma "personalidade de exceção", no sentido hegeliano, e se posiciona entre o Criador e a criatura. O jogo sonoro de "Um vento de sombras..." amplia o conceito da arte simbólica. Notam-se não só o uso da aliteração, da coliteração (sombra, sopra, cinzas, sou, sobre) e da unificação dos sons do soprar do vento, mas também o uso da sinestesia, das palavras que sugerem interiorização do ato do sentir, da percepção, do movimento, do vago, da 
metáfora da contraposição sinestésica, das imagens oníricas, da nominação, da personificação, do cromatismo, dos oximeros e das antíteses, resultando uma construção artística subjetiva, centrípeta e centrífuga ao mesmo tempo, semelhante a um redemoinho: de fora para dentro e de dentro para fora. Assim, tem-se:

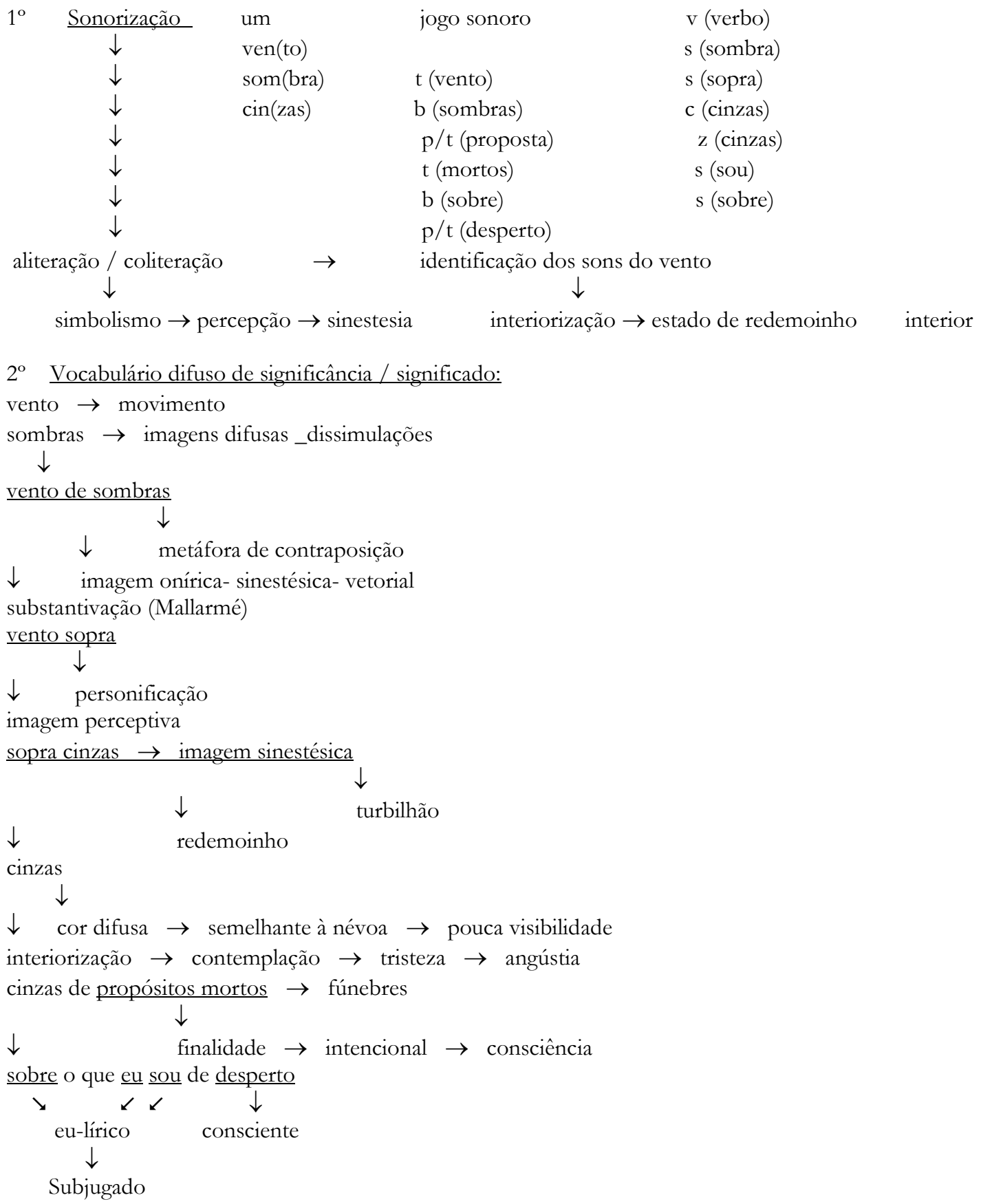

interior

$2^{\circ} \quad$ Vocabulário difuso de significância / significado:

vento $\rightarrow$ movimento

sombras $\rightarrow$ imagens difusas_dissimulações

$\downarrow$

vento de sombras

$\downarrow \quad$ metáfora de contraposição

$\downarrow \quad$ imagem onírica- sinestésica- vetorial

substantivação (Mallarmé)

vento sopra

$\downarrow \quad$ personificação

imagem perceptiva

sopra cinzas $\rightarrow$ imagem sinestésica

cinzas

$\downarrow \quad$ cor difusa $\rightarrow$ semelhante à névoa $\rightarrow$ pouca visibilidade

interiorização $\rightarrow$ contemplação $\rightarrow$ tristeza $\rightarrow$ angústia

cinzas de propósitos mortos $\rightarrow$ fúnebres

Conforme o encadeamento analítico das imagens apresentadas, pertinentes ao texto exposto, pressupõe-se que o vento de sombras, as imagens difusas e oníricas sobrepõem-se à consciência do sujeito lírico em constante estado de letargia, no pouco que lhe resta de 


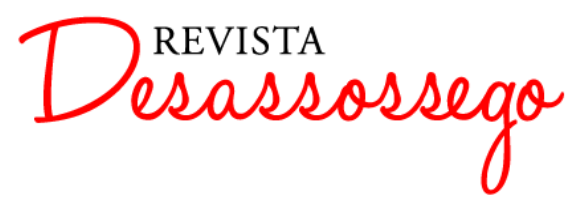

DESASSOSSEGO 15 | JUN/2016 | ISSN 2175-3180

DOI: http://dx.doi.org/10.11606/issn.2175-3180.v8i15p178-195

lógica, entre o "ser criador" e o "ser criatura". Por fim, em "cai de um firmamento desconhecido um orvalho morno de tédio. Uma grande angústia inerte manuseia-me a alma por dentro e, incerta, altera-me, como a brisa dos perfis das copas", confirma-se que a arte pode ser encarada não como sombra de significação, mas que aparece à superfície do quase-discurso por meio de efeitos de expressão, não de conteúdo. E mesmo admitindo que há uma expressão do real, do concreto, e outra da ilusão do real ou mesmo irreal, ou ainda, do abstrato, não se trata de meramente distinguir entre elas, mas de sabê-las, todas, constituintes da espessura de algo que, como o signo, é formado necessariamente por um verso e um reverso. E diante dessa postura, a análise viável é a que vê, que pratica uma atenção flutuante dos signos simbólicos, polissêmicos do texto. O verbo cair, semelhante à ação da chuva ou à da neblina; o uso das formas nominais dos verbos, a nominação em firmamento desconhecido e a metáfora sinestésica do contraponto em orvalho morno, compõem, primeiramente, o vago, o difuso, passando à idealização de um mundo metafísico (teocêntrico), pelo uso do termo firmamento, que pressupõe o céu, o além, o lugar dos desígnios dos deuses. Embora, um lugar desconhecido. O resultado é um orvalho morno. $\mathrm{O}$ vocábulo inicial remete às fagulhas líquidas (frias), difusas, em contraste com morno, algo tátil, referindo-se ao contínuo, ao demorado, ao persistente, ao cotidiano. Esse jogo discursivo produz a dinâmica do texto poético.

A personificação abstrata e o desdobramento reflexivo do enunciado, em "angústia inerte manuseia-me a alma por dentro...” (1999, p.453), mostram que o texto possui um eixo central de onde partem várias modulações. Para trás e para frente: a estrutura e suas secretas alterações dialéticas. De fato, aquilo que, desde a primeira leitura, vai ficando claro para o leitor é o jogo entre a imobilidade e o movimento, o abstrato e o concreto, o real e o irreal, o interior e o exterior, todos percebidos por uma consciência que se esforça por manter a tensão entre esses termos contraditórios. $O$ ato físico sobre o estado de abstração, das imagens trasladadas, integradas pela insidiosa presença da consciência poética, torna-se presente no todo do texto. Tal consciência aponta para a realização efetiva do texto enquanto mediação entre os estados de emoção do sujeito paciente e o da inteligência, isto é, da reflexão criadora do sujeito agente.

As alterações dialéticas, por outro lado, implicam aquilo que se esconde nas próprias dobras da prosa poética: o próprio ato de criar. Assim sendo, o texto espelha o seu jogo mais secreto, instaurando uma espécie de autorreflexão criadora, num contínuo movimento, ao mesmo tempo, centrípeto e centrífugo, ou seja, de fora para dentro e de 


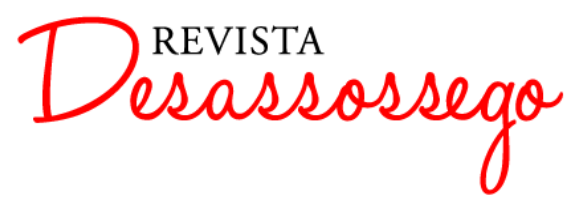

DESASSOSSEGO 15 | JUN/2016 | ISSN 2175-3180

DOI: http://dx.doi.org/10.11606/issn.2175-3180.v8i15p178-195

dentro para fora. Entre o concreto e a abstração, o real e as sombras, o sono e a vigília, geradores do dinamismo criador, o texto encontra o seu ser linguagem: aquilo que transita entre o absoluto e o relativo, quer dizer, entre o silêncio e a palavra. Isto é: uma articulação em que a intensidade do objeto poético (emoções, percepções e imagens) é traduzida pela linguagem e retraduzida pela consciência poética.

\section{Fusão, consciência e isolamento}

As tensões da primeira instância exprimem-se frequentemente por antinomias entre o sujeito paciente e o sujeito agente, marcadas pelo ato de saber não sabendo, bem como por meio do jogo linguístico fônico, semântico e morfo-sintático. Todas as tensões reportam ao estar entre a realidade e a imagem. Isto é, o eu-lírico sente-se imerso no ponto de transição entre a linguagem referencial e a linguagem poética, num estado de mergulho no desconhecido: a arte. Os contrastes, o vago, o difuso, a multiplicidade significativa, as fortes tensões vocabulares, bem como os desdobramentos linguísticos antitéticos permanecem na elaboração poética desta segunda instância. No entanto, ampliam-se o sentido da obra, a postura do sujeito lírico e os recursos significantes de expressão artística. Um traço semântico importante é o fusionismo, ou seja, a tendência para integrar, em um todo, múltiplos pormenores desconexos e para associar e mesclar, numa unidade orgânica, elementos díspares, contraditórios. Uma espécie de tessitura linguística desconexa, de forma e de conteúdo ambíguos.

No trecho:

$\mathrm{Na}$ alcova mórbida e morna a antemanhã de lá fora é apenas um hábito de penumbra. Sou todo confusão quieta... Para quê há-de um dia raiar?... Custa-me o saber que ele raiará, como se fosse um esforço meu que houvesse de o fazer aparecer. Com uma lentidão confusa acalmo. Entorpeço-me. Bóio no ar, entre velar e dormir, e uma outra espécie de realidade surge, e eu em meio dela, não sei de que onde que é este...Surge mas não apaga esta, esta alcova tépida, essa de uma floresta estranha. Coexistem na minha atenção algemada as duas realidades, como dois fumos que se misturam. Que nítida de outra, e de ela essa trêmula paisagem transparente!... (PESSOA, 1999, p. 453).

A alcova mórbida e morna refere-se à floresta do alheamento: a imagem, o mundo do sonho, a poesia, que se distancia do mundo real, a antemanhã de lá fora. Esta, na realidade artística, é apenas um hálito de penumbra. A obra de arte, nesse sentido, não é o espelho ou reflexo do mundo real. Ela aponta para um real, como imagem na mente do leitor, mas que não passa de simulacro de um real irreal, existente, único e exclusivamente, 


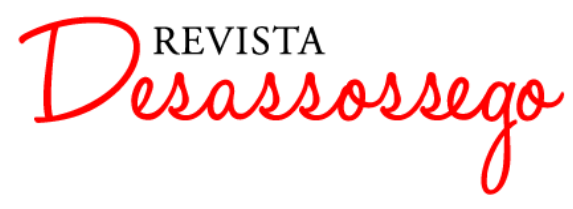

DESASSOSSEGO 15 | JUN/2016 | ISSN 2175-3180

DOI: http://dx.doi.org/10.11606/issn.2175-3180.v8i15p178-195

na obra de arte. Os recursos estilísticos de Fernando Pessoa, no texto, se propõem a criar uma rede complexa de tecido linguístico descontínuo em que a palavra acaba por reconquistar sua originalidade e consistência, mesmo preservando o estado de desintegração lógica de seus termos. Assim, são visíveis as incongruências, as ambiguidades, as técnicas da fusão e as das metáforas de oposição, de genitivos, de justaposição e do contraponto, como: confusão quieta / lentidão confusa / boio no ar / velar e dormir / alcova trépida / floresta estranha / atenção algemada / trêmula paisagem transparente.

Com efeito, estes recursos estão intimamente relacionados a uma visão da arte que se distancia da frase como forma articulada, sintática e semanticamente, do modelo tradicional. Pode-se falar sobre uma prosa poética hostil à frase enquanto norma de composição direta, resultando, em consequência, num novo modo de fusionismo, diferente daquele produzido pelo estilo barroco, em cujos fenômenos se traduzem pelo fragmentarismo. Uma composição nominal que, pelo sentido, transforma, por exemplo, adjetivos em predicativos, semelhantes a

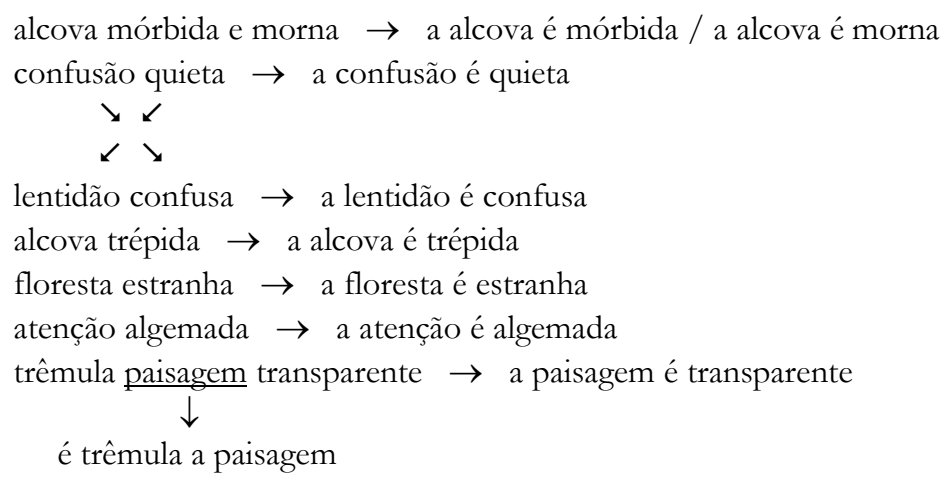

Desse modo, a substantivação, que é uma característica do fragmentarismo, é, ainda, evidente no uso de determinadas expressões do tipo: "hálito de penumbra" e no jogo das frases longas, ora subordinadas, ora coordenadas e no intercalar, de períodos simples curtos, bem como pelo jogo linguístico, sintático, do perguntar, do interrogar e do afirmar: "Para quê há-de um dia raiar?...", "Bóio no ar...", "Que nítida [...] paisagem transparente!...”. A conjunção de formas intensifica a técnica do fragmento, não só no plano formal da composição, mas consegue, também, reforçar o isolamento daquilo que é mostrado, criando uma espécie de mistério, aumentando a tensão, o contraste e, enfim, produzindo uma arte que é, ao mesmo tempo, conjunção e isolamento.

O sujeito lírico mostra-se confuso, mas tem consciência das duas realidades: a do mundo real e a do mundo da arte. Elas se misturam na atenção algemada do poeta, porém, 
na arte, elas são bem nítidas, bem distintas. Daí a exclamação final: "Que nítida de outra e de ela essa trêmula paisagem transparente!"

Os questionamentos das citações anteriores e do trecho "E quem é esta mulher que comigo veste de observada a floresta alheia? Pra que é que tenho um momento de perguntar? Eu nem sei querê-lo saber ...” (PESSOA, p.452) evocam o estado de (con)fusão do sujeito e do poético. Um confronto entre o querer fazer e o querer saber. Por detrás desse jogo (do fazer e do saber), marca visível da arte pessoana, estão os modos de visão da multiplicidade na divisibilidade e vice-versa, e da percepção poética do real como simulacro, como dissimulação conflituosa.

A dissimulação, portanto, é o paradigma que delineia o perfil de toda poética de "Na floresta do alheamento". Esta poderia ser chamada de poética da dissimulação do já dissimulado. Esse tipo de poética tomou vida na modernidade, numa sociedade em que a palavra se reduziu pelo valor de troca e acabou por anular a própria memória de real. Uma sociedade na qual a imagem tornou-se a forma final de reificação, isto porque, a desmaterialização dos bens gerou uma linguagem tecnológica, virtual que se refere a um vazio da realidade, produzindo, em decorrência, um real aparente. O desenvolvimento tecnológico e sua consequente desmaterialização e desintegração da vida social se traduzem no surgimento de simulacros que substituem o mundo real por outro artificial, o qual, graças aos recursos de linguagem, passa a se referir cada vez mais a si mesmo. Nessa ordem de raciocínio, a linguagem transforma-se em simulacro de uma realidade vazia que, no processo de comunicação, ganha autonomia frente ao referencial externo. Por outro lado, a linguagem poética, consumida por esse processo de (dis)simulação, é obrigada a se desdobrar, criando a dissimulação da dissimulação, uma espécie de metáfora da metáfora. Ora, se com o esvaziamento da realidade, o signo se emancipa de sua função referencial, instaurando a cisão entre o signo e o objeto; a criação artística, também, adquire novo processo: o da imagem da imagem do real (im)provável.

Os sentidos dos contrários que se misturam, promovendo o fusionismo fragmentário e múltiplo, atestam o estado de angústia criadora do sujeito lírico. A presença inesperada do vocábulo "mulher" e sua personificação pelo pronome demonstrativo esta, promovem, no leitor, um estranhamento. O mal-estar é ampliado pela expressão subsequente: "comigo veste de observada essa floresta alheia". O poeta, com isso, intensifica a ambiguidade discursiva para, assim, elevar a sua linguagem poética acima da linguagem que o sistema tecnológico produziu. Observe que a estranheza e a incongruência 
semântica dos termos não poderia ser a continuação metafórica das metáforas precedentes, nem poderiam ser, da mesma forma, entendidas literalmente. No fragmento,

A alcova vaga é um vidro escuro através do qual, consciente dele, vejo esta paisagem,...e essa paisagem conheço-a há muito, e há muito que com essa mulher que desconheço erro, outra realidade, através da irrealidade dela. Sinto em mim séculos de conhecer aquelas árvores e aquelas flores e aquelas vias em desvios e aquele ser meu que ali vagueia, antigo e ostensivo ao meu olhar, que o saber que estou nesta alcova veste de penumbras de ver... (PESSOA, p. 453).

a metáfora da metáfora das primeiras palavras, as recorrências vocabulares de alcova, vaga, vagueia, paisagem, há muito, bem como mulher, desconhecido, penumbra...formam uma compreensibilidade incompreensível, uma estranheza semântico-vocabular que distancia o leitor da possibilidade de afirmar o que ele (o texto) diz, mas do como ele diz. O estilo, então, atrai a atenção sobre si própria. E, enquanto criação original de si mesmo, é, também, uma recriação contínua da linguagem, o que equivale a um rompimento da cadeia de significância lógica. Daí o poeta afirmar: ...essa paisagem conheço-a há muito, e há muito que com essa mulher que desconheço erro, outra realidade, através da irrealidade dela.

Com efeito, o texto poético é um continum, no processo histórico e é, ele em si, logo, original. Cada composição possui o seu todo e este não se repete, é sempre novo, é sempre desconhecido. E, como arte, apresenta, dialeticamente, outra realidade, nunca a mesma. Constrói-se, no entanto, através da irrealidade da arte anterior, como forma de ruptura com a tradição ou com os modelos preestabelecidos ou, ainda, produz outra realidade além do real. "Na floresta do alheamento", as imagens-símbolo são moduladas pelo ato de desautomatização e significam, primeiramente, elas mesmas em relação ao contexto geral da prosa poética. Por isso, o poeta recorre, constantemente, aos verbos sentir e ver, bem como às conjunções de palavras que, no todo, se negam e se afirmam:

De vez em quando pela floresta onde de longe me vejo e sinto, um vento lento varre um fumo, e esse fumo é a visão nítida e escura da alcova em que sou actual, [...]. Depois esse vento passa e torna a ser toda só ela a paisagem daquele mundo...Outras vezes este quarto estreito é apenas uma cinza de brumas no horizonte dessa terra diversa.... E há momentos em que o chão que ali pisamos é esta alcova visível. (PESSOA, p. 453).

A arte, como metáfora da metáfora, forma o contraste entre o sentir e o ver; entre ser passado, no tempo e no espaço, e o ser atual, no sentido do sempre novo, original; entre a realidade (quarto estreito-chão) e a linguagem (terra diversa / alcova visível), entre o 
sonho e o estar desperto; entre o ser eu e essa mulher e, por fim, entre expressões do tipo "fogo negro", “ânsia passiva”, "vida falsa” (fora do mundo real). Desse modo, a junção dos contrários conforma o fazer arte que, em outras palavras, promove a metamorfose semântica dos termos no seu todo. Compondo, em consequência, a transposição do sentido denotativo para o mundo da arte. Isto é, a realidade se desfaz em imagens plurissignificantes, próprias do mundo da criação. O prazer estranho e o confuso do ato de criar, o estar entre a realidade (física) e a arte; o ser pessoa e o ser poeta, a relação poetaarte, o encontro do artista com a sua poética; a concepção da arte descompromissada, o enamorar-se e, também, a consciência de que a infelicidade é maior do que a felicidade, tudo isso compõe a semântica da prosa poética da citação a seguir:

Ó felicidade baça!... O eterno estar no bifurcar dos caminhos!... Eu sonho e por detrás da minha atenção sonha comigo alguém... E talvez eu não seja um sonho desse Alguém que não existe... Lá fora a antemanhã tão longínqua! A floresta tão aqui ante outros olhos meus!

E eu, longe dessa paisagem quase a esqueço, é ao tê-la que tenho saudades dela, é ao percorre-la que a choro e a ela aspiro...[...] E subianos o choro à lembrança, porque nem aqui, ao sermos felizes, o éramos...[...] uvas... (PESSOA, p.454).

O texto parte de uma técnica de evocar, sugerir e de evitar a explícita nomeação das coisas, para imagens que estabelecem um foco interior de emoção, que, ao mesmo tempo, põem-se no lugar de uma ideia. Produz, também, modos indiretos de exposição de conceitos, com a associação particular, em uma espécie de simbolismo que pretende não ser plenamente entendido, como uma criação hipotética. Assim, o processo criativo não se envolve, necessariamente, com os mundos da verdade e do fato, nem se afasta deles, mas entra em todos os tipos de relações com eles. Para Northrop Frye, a arte tem, com a realidade, uma relação nem direta, nem negativa, mas potencial. Assim, a vitória do poético sobre a linguagem padrão está na técnica de expressão que o poeta, consciente em seu refúgio, funde, (des)constrói e cria. A desautomatização da linguagem, marcada pela duplicidade significativa e pela conjunção de palavras de sentidos opostos, como em

$$
\begin{aligned}
& \text { movimento parado das árvores, } \\
& \text { sossego inquieto das fontes, } \\
& \text { hálito indefinível do ritmo, } \\
& \text { horas de desassossego feliz, } \\
& \text { (PESSOA, p.455), }
\end{aligned}
$$

forma o ato do constructo artístico que, em decorrência, mistifica o real e transforma o aparente real em tempo-espaço-memória: "Ali vivemos um tempo que não sabia decorrer, um espaço para que não havia pensar em poder-se medi-lo. Um decorrer fora do Tempo. 
Uma extensão que desconhecia os hábitos" (Ibidem, p.455). No tempo-espaço-memória, a arte cria a imagem que não é a do real em si. Por isso, a obra de arte transporta o sujeito lírico, o criador e seus leitores para a realidade-imagem, própria da poesia. O leitor é convidado a navegar, por meio dos órgãos dos sentidos, nas e pelas palavras, para que possa viver a realidade da Arte: poesia como simulação dissimulada, arte descompromissada, sem finalidade. Daí a plenitude do "ser" e do "fazer artístico".

\begin{abstract}
Orla de mares desconhecidos tocavam, no horizonte de ouvirmos, praias que nunca poderíamos ver, e era-nos a felicidade escutar, até vê-lo em nós, esse mar onde sem dúvida singravam caravelas com outros fins em percorrê-lo que não os fins úteis e comandados da Terra.[...] Dormimos ali acordados dias, contentes de não ser nada [...] Julgávamo-nos imortais... (PESSOA, 1999, p. 455).
\end{abstract}

Daí a afirmação da terceira instância, isto é, a arte que se autoteoriza, a arte pela arte - o retorno. Nesta instância, a prosa poética pessoana de "Na floresta do alheamento" externa, pela ordem vocabular, a construção da arte pela arte. Configura-se a si mesma. O sujeito lírico conjuga num só corpo forma o conteúdo-arte. Expressa a técnica de seu construto meta-poético, uma criação surreal, feita de imagens sinestésicas, de enfáticas recorrências.

\footnotetext{
Quero ser tal qual quis ser e não sou. Se eu cedesse destruir-me-ia. Quero ser uma obra de arte, da alma pelo menos [...]. Por isso me esculpi em calma e alheamento e me pus em estufa, [...] - onde a minha artificialidade, flor absurda, floresta em afastada beleza. (PESSOA, 1999, p.139).
}

De modo genuíno, a escrita tem, no seu elaborar, características individuais, relativas à escrita-sujeito: escritura da escritura. Como tal, não corresponde a uma determinada função como ato consciente de uma individualidade, mas à possibilidade da própria escrita se designar e inscrever a si mesma como ato: "Eu não escrevo em português. Escrevo eu mesmo”. (PESSOA, p.391). E, ao mesmo tempo, demonstra que a arte, idêntica aos sonhos, é mais real: "E perante a realidade suprema da minha alma, tudo o que é útil e exterior me sabe a frívolo e trivial ante a soberana e pura grandeza dos meus mais vivos e frequentes sonhos. Esses, para mim, são mais reais”. (Idem, p.71).

Destarte, esse processo de uma escritura autorreferente implica também a presença e a aceitação crítica ou não da existência do outro que, na obra específica, podem ser as personagens literárias, relacionadas aos heterônimos e a Fernando Pessoa ele mesmo, aos atores que povoam o seu mundo poético e às personalidades literárias de diversas épocas, estilos e gêneros. 
Criei em mim várias personalidades. Crio personalidades constantemente. Cada sonho meu é imediatamente, logo ao aparecer sonhado, encarnado numa outra pessoa, que passa a sonhá-lo, e eu não. Para criar, destruí-me; tanto me exteriorizei dentro de mim, que dentro de mim não existo senão exteriormente. Sou a cena viva onde passam vários atores representando várias peças. (p.283-284).

Partindo desse pressuposto, a escritura, ao falar de si própria, inclui, em seu universo literário, o outro e, ao mesmo tempo, inventa-se e deixa-se inventar pela alteridade. Do mesmo modo, inventa outro, dentro ou fora dela mesma, não sem provocar, logicamente, uma relação de inclusão/exclusão do outro em sua interioridade: um modo de aceitação e, ao mesmo tempo, de negação. Esse outro são as diversas figuras existentes, que influenciam mais ou menos na criação do poeta prosador. Assim, o aspecto que caracteriza o Livro do desassossego e, em especial, no trecho referente ao "Na floresta do alheamento" como metaficção é o seu paradoxo interno autoconsciente que cria tanto o distanciamento quanto o envolvimento do outro. Por isso, não é escrita como a vida, mas vida como a escrita. Não representa, é:

Ninguém me conheceu sob a máscara da igualha, nem soube nunca que era máscara, porque ninguém sabia que neste mundo há mascarados. Ninguém supôs que ao pé de mim sempre outro, que afinal era eu. Julgaram-me sempre idêntico a mim (PESSOA, p.383).

Desse modo, o espaço, "Na floresta do alheamento", é a linguagem de si mesma no seu processo de construção: “A arte consiste em fazer os outros sentirem o que nós sentimos, em libertá-los deles mesmos, propondo-lhes a nossa personalidade para especial libertação" (p. 255). E, também, criar a figura artificial que se multiplica em outras figuras virtuais, sem, no entanto, reduzir-se a nenhuma delas, inserida em uma prosa "sem fato" e em uma série de fragmentos de sonhos e de romances, uns dentro de outros, em uma história sem vida. Uma confissão poética fingida que funde linguagem poética e metalinguagem:

[...] não sei se existo, sinto possível o ser um sonho de outrem, afigura-se-me, quase carnalmente, que poderei ser personagem de uma novela, movendo-me, nas ondas longas de um estilo, na verdade feita de uma grande narrativa. [...] E isto faz com que sonhe a pergunta se não será tudo [...] uma série entreinserta de sonhos e romances, como caixinhas dentro de caixinhas maiores - umas dentro de outras e estas em mais -, sendo tudo uma história com histórias, como as Mil e Uma Noites, decorrendo falsa na noite eterna. (PESSOA, p. 275).

Pode-se dizer que a prosa poética evidencia a necessidade maneirista de Fernando Pessoa de inventar e, ao mesmo tempo, de resgatar a identidade da arte, aquilo que é próprio dela. Como ficção de si mesma, indica a perda da aura (BENJAMIN, 2000, p. 10), 


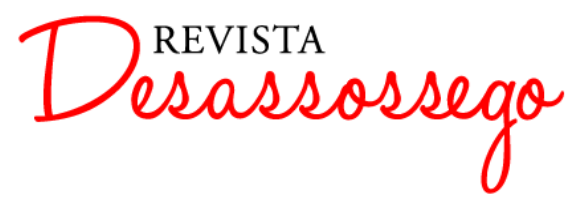

porque dessacraliza o mito da criação, colocando a nu o processo de produção da obra de si para si própria.

\section{Considerações Finais}

Em "Na floresta do alheamento", as três instâncias formam a arte fingimento, isto é, dissimulação da dissimulação, "impressões sem nexo, nem desejo de nexo". Consciente das condições de sua própria produção e recepção, esta arte desafia o formalismo estruturalista de sua época e qualquer concepção mimetista de referencialidade que não seja a da própria arte-construção de si mesma. Sua autonomia não está baseada nas teorias realistas de representação, mas na historização e contextualização de si própria. Por isso, o fragmento, como o Livro, é metaficcional, autoereflexivo, autorreferente, sempre consciente de seu status de linguagem artística como processo de construção, construção do espírito: "A única arte verdadeira é a da construção. Mas o meio moderno torna impossível o aparecimento de qualidades de construção no espírito" (PESSOA, p. 244). Como escritura autorreferente, expõe que não há nada fora do texto. Nele, não há um centro, tudo é relativizado. Tudo e todos são reduzidos a fragmentos, muitos incompletos, outros sem nexo. O que resta não são os fatos, pois ficções do desenredo, apenas texto sobre texto, um significante confessional de um fingidor autoconsciente, de íntima e profunda experiência poética, de vivência artística plena.

\section{REFERÊNCIAS}

BAUDRILLARD, Jean. Simulacros e simulações. Lisboa: Relógio D’Água, 1991.

BENJAMIN, Walter. A obra de arte na época de sua reprodutividade técnica. In: Pensadores. São Paulo: Abril Cultural, 2000.

FRYE, Northrop. Anatomia da Crítica. São Paulo: Cultrix, 2011.

MALLARMÉ, Stéphane. Oeuvres complètes. Paris: Gallimard, 2003.

MUKAROVSKY, Jan. Linguagem-padrão e linguagem-poética". In. Escritos sobre estética e semiótica sobre a arte. Lisboa: Estampa. 1993.

PESSOA, Fernando. Livro do desassossego. São Paulo: Cia das Letras, 1999. 